\title{
DESKRIPSI KEMAMPUAN BERPIKIR KRITIS MATEMATIS AWAL SISWA PADA INDIKATOR REASON DAN INFERENCE MELALUI PENDEKATAN REALISTIC MATHEMATICS EDUCATION
}

\author{
Shindy Ekawati ${ }^{1}$, Lidya Gunawan ${ }^{2}$ \\ Universitas Cokroaminoto Palopo ${ }^{1,2}$ \\ shindy.ekawati@uncp.ac.id ${ }^{1}$
}

\begin{abstract}
Abstrak
Penelitian ini adalah penelitian kualitatif yang bertujuan untuk mendeskripsikan kemampuan berpikir kritis matematis awal siswa SMP Negeri Satap Paccerakang pada indikator Reason dan Inference melalui pendekatan Realistic Mathematic Education pada materi bangun ruang sisi datar. Subjek penelitian ini adalah 3 orang siswa kelas VIII SMP Negeri Satap Paccerakang yang berkategori pengguna, pelajar dan pemula. Instrumen penelitian ini adalah peneliti sendiri. Penelitian ini juga digunakan instrumen pendukung yaitu; (1) tes kemampuan awal berpikir kritis matematis, (2) pedoman wawancara. Data yang diperoleh dianalisis dengan analisis kualitatif dimana peneliti melakukan reduksi terhadap data yang diperoleh. Hasil penelitian menunjukkan kemampuan berpikir kritis matematis awal siswa dengan kategori tinggi yaitu terletak pada indikator Reason, kemampuan awal berpikir kritis matematis siswa dengan kategori sedang yaitu terletak pada indikator Inference, dan kemampuan awal berpikir kritis matematis siswa dengan kategori rendah tidak mecapai salah satu indikator manapun.
\end{abstract}

Kata Kunci : kemampuan awal, berpikir kritis matematis, Realistic Mathematics Education

\section{A. Pendahuluan}

Kemampuan awal siswa adalah persyarat yang harus dimiliki oleh setiap siswa agar dapat mengikuti pembelajaran dengan lancar sehingga mereka bisa memahami materi yang diajarkan. Berbagai fakta yang telah ditemukan membuktikan bahwa kemampuan awal matematika siswa masih kurang. Hal ini disebabkan pada saat proses pembelajaran guru lebih fokus dalam menyelesaikan materi pembelajaran sesuai dengan silabus yang telah ditentukan. Guru mempercepat pembelajaran karena mengejar waktu yang telah direncanakan meskipun siswa belum sepenuhnya mengerti. Siswa juga hanya bisa menghafal pelajaran dan kurang berlatih mengerjakan soal-soal 
latihan matematika, maka dari itu siswa akan selalu mengalami kesulitan jika kesalahan sebelumnya tidak diperbaiki.

Salah satu harapan yang ingin dicapai pada pembelajaran matematika di SMP berdasarkan kurikulum yang berlaku pada saat ini adalah memilikinya kemampuan berpikir kritis. Kemampuan berpikir kritis khususnya berpikir kritis tingkat tinggi sangat diperlukan siswa, terkait dengan kebutuhan siswa yang memecahkan masalah yang dihadapi dalam kehidupan sehari-hari. Kemampuan berpikir kritis muncul pada diri siswa apabila selama proses belajar dalam kelas, guru membangun pola interaksi dan komunikasi yang lebih menekankan pada proses pembentukan pengetahuan secara aktif oleh siswa (Elisna, 2017).

Saat guru mengajar guru selalu menuntut siswa untuk belajar tetapi jarang memberikan pelajaran tentang bagaimana siswa untuk belajar, bahkan guru menuntut siswa agar menyelesaikan masalah, tetapi jarang mengajarkan bagaimana siswa seharusnya menyelesaikan masalah tersebut. Apalagi dengan perkembangan zaman sekarang ini yang semakin menuntut kualitas pada manusia. Perlu adanya pembaharuan di lingkungan pendidikan yang mengarahkan siswa agar senantiasa dalam berpikir kritis. Berpikir kritis penting bagi siswa karena dalam berpikir kritis siswa dapat menganalisis atau mencari solusi serta membuat keputusan terhadap suatu masalah secara sistematis khususnya pada pembelajaran (Djafar, 2014).

Berdasarkan observasi yang telah dilakukan, kenyataan ini dijumpai pula pada siswa kelas VIII SMP Negeri Satap Paccerakang yang merasa kesulitan dalam menyelesaikan soal yang membutuhkan kemampuan dalam menganalisis. Hal ini dikarenakan siswa hanya mencontoh apa yang telah dikerjakan guru, dan dalam menyelesaikan soal, siswa beranggapan bahwa cukup dikerjakan seperti apa yang dicontohkan. Akibatnya siswa kurang memiliki kemampuan dalam menyelesaikan soal dengan alternatif lain. Siswa juga kurang memperoleh kesempatan secara bebas untuk mengekspresikan dirinya. Kemampuan menganalisis ini adalah bagian dari kemampuan berpikir kritis. Cara berpikir kritis meliputi pemikiran analisis dengan tujuan untuk mengevaluasi apa yang telah dibaca. 
Selain itu pembelajaran matematika yang digunakan guru menenkankan pada penguasaan keterampilan dasar menghitung (basic skills) yang bersifat procedural. Hal tersebut dapat dilihat dari soal-soal yang diberikan saat ulangan sama persis seperti contoh, hanya saja angka yang diberikan diubah. Dilihat dari pekerjaan siswa dalam menyelesaikan soal, hampir tidak ada siswa kelas VIII SMP Negeri Satap Paccerakang yang menunjukkan bahwa mereka berpikir kritis dalam menyelesaikan soal tersebut.

Berpikir kritis matematis adalah dasar proses berpikir untuk menganalisis argument dan memunculkan gagasan terhadap tiap makna dalam mengembangkan pola pikir secara logis. Hal tersebut juga diungkapkan oleh Noer (Jumaisyaroh, 2015) bahwa berpikir kritis matematis adalah sebuah proses yang mengarah pada penarikan kesimpulan tentang apa yang harus kita percayai dan tindakan yang akan kita lakukan. Menurut Susanto (Jumaisyaroh, 2015), berpikir kritis matematis merupakan suatu kegiatan berpikir tentang gagasan atau ide yang berhubungan dengan masalah yang telah diberikan.

Salah satu faktor yang mempengaruhi rendahnya kemampuan berpikir kritis siswa adalah metode maupun model pembelajaran yang digunakan oleh guru pada saat pembelajaran. Guru lebih sering menggunakan metode pembelajaran yang belum melibatkan siswa secara aktif dan kurang melatih kemampuan berpikir kritis siswa. Padahal untuk menyelesaikan soal-soal matematika siswa dituntut harus mampu berpikir kritis dengan memiliki kemampuan berpikir kritis, siswa akan mampu menganalisis pertanyaan dan mencari solusi dari masalah yang ada pada soal. Pembelajaran disekolah hendaknya siswa dilatih untuk memiliki keterampilan berpikir kritis dalam memperoleh, memilih dan mengolah informasi agar dapat bertahan pada keadaan yang selalu berubah dan kompetif (Elisna, 2017).

Proses mengerjakan soal matematika biasanya siswa kurang berhati-hati sehingga seringkali melakukan kesalahan yang berakibat fatal pada jawabannya. Seperti yang dinyatakan oleh Sugiman, dkk (Salwah, 2014) bahwa siswa yang tidak mampu mengerjakan masalah matematis disebabkan karena ketidakmampuan memahami konsep, tidak memiliki strategi yang tepat, kurang mampu 
mengkomunikasi apa yang telah dikerjakannya, dan melakukan perhitungan kurang akurat.

Solusi mengatasi masalah tersebut adalah dengan cara memperbaiki cara pembelajaran di kelas dengan menggunakan model pembelajaran yang tepat dan efektif. Model pembelajaran matematika yang dapat digunakan untuk melatih kemampuan berpikir kritis matematis siswa salah satunya adalah dengan menggunakan Pendekatan Ralistic Mathematics Education.

Pendekatan Realistic Mathematics Education di Indonesia dikenal dengan istilah Pendidikan Matematika Realistik Indonesia. Realistic Mathematics Education merupakan salah satu pendekatan pembelajaran yang berasumsi perlu adanya pengkaitan antara matematika dengan realitas yang ada dan dapat dijumpai dalam kehidupan sehari-hari. Realistic Mathematics Education dijadikan sebagai solusi terhadap permasalahan yang dihadapi dalam pembelajaran, dengan pendekatan Realistic Mathematics Education siswa aktif pada pembelajaran sehingga akan tercipta kondisi pembelajaran student centered atau pembelajaran berpusat pada siswa.

Penerapan Realistic Mathematics Education bisa menjadi inovasi dan alternative untuk mengatasi masalah khusus pada penelitian ini. Menurut Alfriansyah (2017) Realistic Mathematics Education diharapkan mampu member sumbangsih kepada siswa agar lebih aktif dalam pembelajaran, sebab pembelajaran harus berpusat pada siswa.

\section{B. Metode Penelitan}

Penelitian ini dilaksanakan di SMP Negeri Satap Paccerakang, yang berada di kecamatan Ponrang Selatan Kabupaten Luwu Provinsi Sulawesi Selatan. Adapun Waktu penelitian atau observasi dilakukan pada tahun ajaran 2019/2020 semester genap antara bulan Februari sampai Juni 2020 di SMP Negeri Satap Paccerakang. Jenis penelitian ini adalah penelitian deskriptif dengan pendekatan kualitatif. Instrumen Penelitian yang digunakan adalah tes kemampuan berpikir kritis matematis dan pedoman wawancara.

Proses pengumpulan data dalam penelitian ini dilakukan melalui pemberian tes kemampuan berpikir kritis matematis siswa. Tes tersebut digunakan untuk memperoleh 
data tentang tingkatan pengkategorian kemampuan berpikir kritis matematis awal siswa. Selanjutnya melakukan wawancara dan observasi untuk menelusuri kemampuan berpikir kritis matematis siswa yang diberikan serta kemungkinan-kemungkinan penyelesaian lain yang dapat dilakukan. Kemampuan subjek penelitian dipelajari melalui interpresentasi yang diberikan subjek dalam menjawab pertanyaan wawancara. Setelah data terkumpul dan dianalisis sampai ditemukan jawaban dari penelitian, selanjutnya melakukan pemeriksaan keabsahan data. Menurut Sugiono (dalam Arniawati, 2017) untuk menilai suatu keabsahan data hasil penelitian kualitatif, maka dilakukan pengujian: (1) pengujian kredibilitas, (2) pengujian transferabilitas, (3) pengujian dependabilitas, (4) pengujian konfirmabilitas.

Analisis data kualitatif merupakan proses berkelanjutan yang membutuhkan refleksi terus-menerus terhadap data, mengajukan pertanyaanpertanyaan analisis dan menulis catatan singkat sepanjang penelitian (Creswell, 2012). Data yang telah dikumpulkan dianalisis dengan menggunakan analisis data non statistik karena penelitian ini merupakan penelitian kualitatif. Analisis dilakukan secara mendalam pada siswa tentang pemecahan masalah setelah siswa dikategorikan berdasarkan kemampuan awalnya. Analisis data dilakukan terbatas pada apa yang dikerjakan siswa. Langkah-langkah menganalisis data sebagai berikut:

1. Menelaah seluruh data yang tersedia dari berbagai sumber, yaitu hasil tes kemampuan berpikir kritis matematis, pedoman wawancara dan lembar kerja siswa.

2. Reduksi data adalah kegiatan yang mengacu pada proses menyeleksi, memfokuskan, mengabstraksikan, dan mentransformasikan data mentah. Penelitian ini dilakukan dengan membuat rangkuman yang terdiri dari inti, proses, pernyataan-pernyataan yang sesuai dengan tujuan penelitian. Kata-kata subjek yang tidak sesuai dengan tujuan penelitian dihilangkan. Validasi data dilakukan pada saat sebelum penelitian dilakukan.

3. Penyajian data yang meliputi pengklarifikasian dan identitas data, yaitu menuliskan kumpulan data yang terorganisir dan terkategori sehingga 
memungkinkan untuk menarik kesimpulan dari data tersebut. Penelitian ini, data hasil tes dikategorikan berdasarkan indikator pada setiap aspek yang diamati.

4. Menafsirkan data/menarik kesimpulan penelitian dari data yang sudah dikumpulkan dan memverifikasi kesimpulan tersebut. Penarikan kesimpulan dilakukan berdasarkan analisis terhadap data yang telah dikumpulkan baik melalui tes terhadap subjek. Hal ini dilakukan dengan cara membandingkan hasil pekerjaan subjek dengan hasil tes sehingga dapat ditarik kesimpulan yang benar tentang kemampuan berpikir kritis matematis yang dimiliki oleh siswa.

\section{Hasil Penelitian dan Pembahasan}

Masalah yang digunakan dalam penelitian adalah masalah mengenai bangun ruang sisi datar. Masalah tersebut disusun sesuai dengan perjenjangan indikator kemampuan berpikir kritis yang meliputi Reason dan Inference. Mengindentifikasi kemampuan berpikir kritis pada setiap subjek, peneliti berupaya untuk mengetahui metode yang digunakan subjek untuk menyelesaikan masalah-masalah yang diberikan melalui deskripsi dari peneliti.

Langkah awal dalam penelitian ini adalah melakukan tes kemampuan awal berpikir kritis matematis berupa soal essai sebanyak 2 nomor dan melakukan tes wawancara. Memilih subjek penelitian, peneliti melihat hasil dari tes kemampuan awal berpikir kritis matematis dan tes wawancara yang diberikan, sehingga terpilihlah subjek yang berkemampuan berpikir kritis tinggi (Ignasius Leonard P), kemampuan berpikir kritis Sedang (Lorensia), dan kemampuan berpikir kritis Rendah (Ardianza K). Pembahasan hasil penelitian ini akan menjelaskan secara rinci hasil penelitian berdasarkan indikator berpikir kritis.

Kemampuan berpikir kritis Subjek Berpikir Kritis Tinggi untuk soal pertama yaitu subjek sudah memenuhi indikator dengan baik terlihat dari tes yang diberikan subjek sudah memahami masalah yang diberikan dengan menuliskan apa yang diketahui dan ditanyakan dari masalah yang diberikan, subjek menyederhanakan soal dengan mencari apa yang diketahui dan ditanyakan kemudian subjek membuat proses penyelesaiaannya, kemudian subjek melakukan proses penyelesaian dengan 
menguraikan apa yang diketahui dan ditanyakan sehingga menghasilkan jawaban bahwa pendapatan yang lebih besar adalah penjualan dengan kotak besar sebanyak Rp.110.000. Selanjutnya, subjek membuat kesimpulan bahwa yang menghasilkan pendapat yang lebih besar adalah penjualan dengan kotak besar, maka sebaiknya pemillik mengemas susu produknya dalam kotak besar. Artinya subjek sudah melaksanakan indikator Reason. Soal kedua yaitu subjek tidak dapat menyelesaikan soal dengan benar dan tidak mengetahui rumus dari soal yang akan dikerjakan sehingga subjek hanya menuliskan apa yang diketahui namun kesulitan dalam menyelesaikan soal yang diberikan. Terlihat bahwa subjek tidak memahami masalah mengenai prisma segi enam beraturan yang ada pada soal sehingga subjek menjawab dengan hanya mengalikan apa yang diketahui pada soal. Artinya subjek tidak melaksanakan indikator Inference. Dari uraian yang telah dipaparkan yang mengungkapkan bahwa siswa berkemampuan matematika tinggi dapat memecahkan masalah dengan sangat baik. Hal tersebut didukung dengan pendapat Jacob yang mengatakan bahwa terdapat hubungan linear yang signifikan antara berpikir kritis dan kemampuan matematika.

Kemampuan berpikir kritis Subjek Berpikir Kritis Sedang untuk soal pertama yaitu subjek sudah memahami masalah yang diberikan karena subjek menuliskan apa yang diketahui dan ditanyakan dari masalah yang diberikan, subjek menyederhanakan soal yang diberikan dengan mencari apa yang diketahui dan ditanyakan kemudian subjek membuat proses penyelesaiaannya, kemudian subjek melakukan proses penyelesaian dengan menguraikan apa yang diketahui dan ditanyakan walaupun hasil perkalian yang dilakukan kurang tepat dikarenakan subjek keliru dalam memperhhatikan soal yang diberikan. Artinya subjek sudah melaksanakan indikator Reason. Soal kedua yaitu subjek sudah bisa menjawab dan menyimpulkan soal dengan baik. subjek sudah bisa menggunakan strategi untuk menyelesaikan soal dengan benar dan tepat. Artinya subjek sudah melaksanakan indikator Inference. Hasil penelitian yang didapat sejalan dengan penelitian Febryaningrum (2015) yang mengungkapkan bahwa subjek kemampuan matematika sedang tidak melalui tahap tahap memeriksa kembali dan memecahkan masalah. Dari uraian yang telah dipaparkan sesuai dengan 
pendapat Jacob (2011) yang mengatakan bahwa terdapat hubungan linear yang signifikan antara berpikir kritis dan kemampuan matematika.

Kemampuan berpikir kritis Subjek Berpikir Kritis Rendah untuk soal pertama yaitu yaitu subjek tidak dapat memenuhi indikator. Subjek dikatakan gagal dalam indikator dikarenakan subjek tidak menjawab soal sama sekali. Artinya subjek tidak melaksanakan indikator Reason. Soal kedua yaitu Subjek dikatakan gagal dalam indikator dikarenakan subjek tidak menjawab soal soal sama sekali. Artinya subjek tidak melaksanakan indikator Inference. Dari uraian yang telah dipaparkan sejalan dengan penelitian Nurman (2008) yang menyatakan bahwa siswa yang memiliki kemampuan matematika rendah memiliki kemampuan pemecahan masalah yang kurang baik. Hal tersebut didukung oleh pendapat Haryani (2015) yang menyatakan bahwa seseorang harus memiliki pengetahuan yang cukup dalam memecahkan masalah yang akan dihadapi.

Hasil penelitian untuk subjek kemampuan Berpikir Kritis Tinggi (BKTing), subjek kemampuan Berpikir Kritis Sedang (BKSed) dan subjek kemampuan Berpikir Kritis Rendah (BKRen) menunjukkan perbedaan kemampuan dari masing-masing subjek dimana subjek BKTing hanya memenuhi 2 indikator saja sedangkan subjek BKSed telah memenuhi 3 indikator dan subjek BKRen tidak memenuhi indikator sama sekali.

Berdasarkan paparan diatas bahwa kemampuan awal dan indidkator berpikir kritis memiliki hubungan logis yang erat satu sama lain. Dalam hal ini kemampuan awal dapat membangun kemampuan berpikir kritis dalam menyelesaikan soal. Jika setiap masalah yang membutuhkan kemampuan berpikir kritis maka hal ini akan memudahkan peserta didik dalam membangun kemampuan berpikir kritis, sebab kemampuan berpikir kritis disusun secara hirarki dari indikator Focus, Reason dan Inference. Serta aspek-aspek kemampuan awal yang terdiri dari pengetahuan, pemahaman, dan penerapan. Menurut Nur (Alfianti, 2008) kemampuan awal adalah sekumpulan pengetahuan dan pengalaman individu yang diperoleh sepanjang perjalanan hidup mereka, dan apa yang ia bawah kepada suatu pengalaman belajar baru. Menurut Sutrisno (Alfianti, 2008) kemampuan awal adalah pengetahuan dan 
keterampilan yang relevan termasuk didalamnya lain-lain latar belakang informasi karakteristik siswa yang telah ia miliki pada saat akan mulai mengikuti suatu program pengajaran.

\section{Kesimpulan}

Berdasarkan hasil penelitian dan pembahasan maka disimpulkan sebagai berikut:

1. Kemampuan berpikir kritis matematis siswa kategori tinggi dalam menyelesaikan tes berpikir kritis sudah baik, kemampuan subjek yaitu terletak pada indikator reason.

2. Kemampuan berpikir kritis matematis siswa kategori sedang dalam menyelesaikan tes berpikir kritis yang dari 2 soal yang diberikan subjek dapat menjawab semua soal walaupun ada kekeliruan jawaban yang diberikan.

Kemampuan subjek yaitu terletak pada indikator inference.

3. Kemampuan berpikir kritis matematis siswa kategori rendah dalam menyelesaikan tes berpikir kritis yang dari 2 soal yang diberikan subjek tidak dapat menjawab sama sekali . Hasil tes menunjukkan bahwa kemampuan subjek belum tercapai.

\section{Daftar Pustaka}

Afiyanti, Y. 2008. Validitas dan Reabilitas dalam Penelitian Kualitatif. Jurnal Keperawatan Indonesia. 12 (2):137-141.

Alfriansyah, E. 2017. Desain Lintasan Pembelajaran Pecahan Melalui Pendekatan Realistic Mathematics Education. Jurnal "Mosharafa",Vol. 6, No. 3

Djafar, Nur Asmah. 2014. Penerapan Model Pembelajaran Examples Non Examples Untuk Meningkatkan Kemampuan Berpikir Kritis Peserta Didik Kelas VIII.K Smp Negeri 4 Sungguminbasa Kabupaten Gowa. Jurnal Bionature, Volume 15, Nomor 2.

Elisna. 2017. Deskriptif Kemampuan Berpikir Kritis Matematis Siswa Pada Teorema Pythagoras Kelas VIIIa SMP Negeri 1 Bua. Skripsi tidak diterbitkan. Palopo: FKIP-UNCP.

Febryaningrum, P. A. 2015. Profil Pemecahan Masalah Matematika Siswa SMP Pada Materi Perbandingan Berdasarkan Taksonomi Solo Ditinjau dari Kemampuan Matematika. (Skripsi tidak dipublikasikan). Universitas Negeri Surabaya. 
Haryani, D. 2015. Profil Berpikir Kritis Siswa SMP dalam Memecahkan Masalah Matematika Ditinjau dari Gaya Kognitif dan Gender. (Disertasi tidak dipublikasikan). Universitas Negeri Surabaya.

Jacob, S. M. 2011. Mathematical Achievement and Critical Thinking Skill in Asynchronous Discussion Forums. Procedia - Social and Behavioral Sciences 31 (2012) 800-804.

Jumaisyaroh, T., Napitupulu, E, E., \& Hasratuddin, H. 2015. Peningkatan Kemampuan Berpikir Kritis Matematis dan Kemandirian Belajar Siswa Smp Melalui Pembelajaran Berbasis Masalah.

Nurman, T. A. 2008. Profil Kemampuan Siswa Sekolah Menengah Pertama dalam Memecahkan Masalah Matematika Open Ended Ditinjau dari Perbedaan Tingkat Kemampuan Matematika Siswa. (Tesis tidak dipublikasikan). Surabaya: Program Pascasarjana UNESA.

Salwah. 2014. Peningkatan Kemampuan Berpikir Kritis Matematis dan habit of striving for accuracy and precision (HSAP) Melalui pendekatan Realistic Mathematics Education (RME) Berbasis Gaya Kognitif Siswa Kelas VII SMPN 5 Bandung. Tesis tidak diterbitkan Bandung: Program Studi Pendidikan Matematika-Universitas Pendidikan Indonesia. 